\title{
LIFE-HISTORY OF LYDA FASCIATA (NORTON), FAM. TENTHREDINIDA.
}

BY RICHARD F. PEARSALL, BROOKLYN, N. Y.

Full-grown larvæ were taken on wild cherry (Prunus) in the latter part of September, igor. Placed in a box over earth, they fed but a day or two, turned a deep green, and, entering the earth two to three inches, formed rounded cells, in which they remained as larvæ all winter, transforming to pupæ just before emergence. They are gregarious, remaining in their web, filled with its mass of exuvia, until full-grown, when, as their growth is completed, individually they drop from it and enter the ground. One which was kept under observation formed a pupa on April $28 \mathrm{th}$, and emerged eight days thereafter. The pupal skin is very thin, showing distinctly the parts of the enclosed imago. This brood commenced emerging April $25^{\text {th }}$, and a few individuals are still coming out, May 3 Ist. In the earlier days the males predominated, later the females. Altogether, 134 males and I 23 females have appeared. Copulation took place at once, the pair remaining in coitu from three to five hours. One female (the first observed) was furnished with a spray of wild cherry, and on the night of the $13^{\text {th }}$ of May deposited $7^{6}$ eggs on the under side of a leaf, extending from the tip half its length. They were laid side by side, in rows of five to seven, from midrib to margir, and in little slits cut in the epidermis of the leaf, being attached by a gummy secretion.

Egg.-Size $1.5 \times .5 \mathrm{~mm}$. Sordid white, glossy, and apparently smooth, opaque.

Hatched May 22 nd, turning to a bright yellow the day before. The young larvæ do not eat the egg shells.

First Stage.-Head round, shining, black at vertex, face and mouthparts paler, eyes black. Body dull orange, deeper along an enlarged substigmatal wrinkled fold, which extends the entire length, giving the body a flattened appearance. Thoracic feet and anal plates black. Above the eyes are movable 3 -jointed antennal-like processes, already mentioned by Packard (5th Report U. S. Entom. Commission), his figure, without doubt, referring to this species. Attached to the sides of the upper anal plate are two similar processes, but apparently 5 -jointed. The young larva immediately congregate and begin to spin a web, attaching another leaf, if possible, to form their domicile, and attack the edges of the leaf, consuming all parts of it. Length, . I 2 . 
May 23. Second stage.-Head darker, a depression on the face between the eyes. Otherwise unchanged. Length.r6.

May 25. Third stage much as before. Length .21.

May 27. Fourth stage.--In this stage the black colour of the head, ventral plates, thoracic feet and antennal appendages is intensified. The substigmatal fold becomes thicker and more solid in colour. The spiracles and a series of broken yellowish lines on each segment subdorsally make a faint lateral stripe, dorsally and sublaterally translucent dull greenish. Length .33 .

May 29. Fifth stage.-Much the same as before. One larva discovered moulting. The head apparently splits apart vertically at the mouth without previous visible distension. After moult the skin is partially eaten, but the head-covers remain in the web. The body of the larva retains its normal colours, but the head and ventral plates with their appendages are glassy and colourless, except the eyes, which are black, and a faint tinge of black about the mouth, and remains so for several hours after moult. Length .56 .

May 3 r. Sixth stage.-A decided thickening of substigmatal fold, which now becomes a reddish orange. The broken markings above it and the subdorsal lines are also heavier and more solid in colour. Translucent intervals darker and presenting a slightly shagreened appearance. Instead of being rounded, the upper ventral plate now" has a central triangular depression, in the bottom of which is set a short. movable spine. This space is dusky yellow. The lower ventral plate has a depression on each side of a rounded longitudinal ridge, with the bottom confusedly punctured. Edge of both plates set sparsely with strong, black setæ. Length .84 .

June I2. Seventh stage.-Much as before. Body strongly wrinkled. Thoracic legs and antennal appendages now translucent greenish, ringed lightly with black at the joint. Length, I.I 5 .

June r4. Eighth stage.-Not changed, except that the thoracic legs are ringed with orange. The tubercles on the $\mathrm{I}$ th segment have increased in size with later moults, but none others seem prominent. Length, I.35.

After feeding two days without further moult, the larvæ as they mature turn a deep green, except the head and anal plates, which remain shining black, feet translucent. At this time they drop from the web and enter the ground for æstivation, there being in our section a spring and fall 
brood. These larve, if placed on any flat surface, turn on their backs and begin at once to web the body fast to it, pushing themselves along under the web with the aid of the folds of the body and the jointed appendages of the anal plates. From my observations I believe this to be the purpose for which these appendages are supplied, supplemented at later stages, when its body becomes heavier, by the spinous process placed on the upper anal plate. After falling from the web and seeking to enter the ground, it assumes the normal position, hitching itself along on its ventral surface with the aid of its head and thoracic legs.

Some of the larva of the $190 \mathrm{I}$ brood remain unchanged in their cell at this date, June $I 6 t h$, and, I presume, will not appear as imagoes until the autumn, thus insuring, as do lepidopterous larve, a perpetuation of the species.

\section{LARVA OF DATANA FROM ARIZONA IDENTIFIED.}

In the March number of The Canadian Entonologist, page 74, I described a, to me, unknown larva, which, according to a statement of Mr. Wm. Beutenmuller, of the American Museum of Natural History of New York, is that of Datana robusta, Strecker. Heretofore the imagoes of 1). robusta had all been taken in Texas, and Dr. Dyar in - Prof. Packard's Bombycine Moths, Vol. I., page rzo, is quoted as saying that the larva of Robusta was yet unknown. Some have claimed that the species described as Robusta too much resembled Perspicua, but it will be seen that the larva is distinct, and the imagines of both these species are entitled to the names as first described. The body colour of Robusta larva is black, and the lines are yellow. Perspicua larva has a body of straze or lemon yellow and eleven pitchy reddish lines in the $3^{\text {rd }}$ or $4^{\text {th }}$ stage, and in the $5^{\text {th stage the body is of the same colour, but the lines }}$ are blackish red, according to Mr. ] ames Angus. In the third stage of Perspicua larva, as described by Dr. Dyar, the body colour is dark red and the stripes bright yellow.

Mr. Beutenmuller wishes it to be known that he alone is responsible that these two larve were not turned over to Mr. L. H. Joutel for figuring. He was on the point of departing from the city, and the larvæ having already contracted, he did not think they would then serve the purpose. $\quad$ R. E. Kunze, Phcenix, Arizona. 